\title{
Monoclonal antibodies targeting cell surface deposited complement fragment C3d potentiate cancer immunotherapy and eliminate antigen loss variants
}

\author{
Martin Skarzynski ${ }^{1 *}$, Margeret Lindorfer ${ }^{2}$, Vicent Butera ${ }^{1}$, Berengere Vire ${ }^{1},{\text { Mohammed Farooqui }{ }^{1}, \text { Christoph } \text { Rader }}^{3}$, \\ Ronald Taylor ${ }^{2}$, Adrian Wiestner ${ }^{1}$
}

From 30th Annual Meeting and Associated Programs of the Society for Immunotherapy of Cancer (SITC 2015) National Harbor, MD, USA. 4-8 November 2015

Treatment-induced loss of targeted cell surface antigens through trogocytosis or internalization reduces efficacy of monoclonal antibody (mAb) therapy of cancer. However, cells that escape therapy mediated by complementfixing mAbs carry covalently deposited complement activation fragments on their cell surfaces, in particular C3d. We hypothesized that cell-associated C3d constitutes a neoantigen that could be exploited to selectively retarget cells escaping from therapeutic mAbs. We generated an anti-C3d IgG1 human/mouse chimeric mAb specific for human C3d that is not competed by fulllength $\mathrm{C} 3$ in human serum.

We then set out to provide proof for the concept that complement-targeting mAbs can retarget cancer cells that survive $\mathrm{mAb}$ therapy. For this purpose, we used cells from chronic lymphocytic leukemia (CLL) patients that had substantially reduced CD20 levels due to in vivo treatment with the anti-CD20 mAb ofatumumab (OFA). The chimeric anti-C3d mAb bound cell surface C3d on these CLL cells ex vivo $\left(\mathrm{K}_{\mathrm{D}}=6.7 \mathrm{nM}\right)$, and mediated complement-dependent, and antibody-dependent cellular cytotoxicity and phagocytosis in vitro. CLL cells opsonized by C3d in vivo and reacted with the anti-C3d mAb in vitro were further $\mathrm{C} 3 \mathrm{~d}$ opsonized, resulting in an amplification that enhanced anti-C3d $\mathrm{mAb}$ binding capacity and killing of target cells.

In vivo, the anti-C3d mAb was effective in reducing tumor growth and extending survival in a mantle cell lymphoma xenograft mouse model. This complement-targeting

${ }^{1} \mathrm{NHLBI}$, Bethesda, MD, USA

Full list of author information is available at the end of the article
mAb also depleted human primary CLL cells in the blood and spleens of xenografted NSG mice. Our results identify anti-C3d mAbs as a means to circumvent antigen loss by specifically and potently augmenting the therapeutic efficacy of complement-fixing mAbs.

\section{Authors' details}

${ }^{1} \mathrm{NHLBI}$, Bethesda, MD, USA. ${ }^{2}$ University of Virginia, Charlottesville, VA, USA. ${ }^{3}$ Scripps Florida, Jupiter, FL, USA.

Published: 4 November 2015

doi:10.1186/2051-1426-3-S2-P372

Cite this article as: Skarzynski et al:: Monoclonal antibodies targeting cell surface deposited complement fragment C3d potentiate cancer immunotherapy and eliminate antigen loss variants. Journal for ImmunoTherapy of Cancer 2015 3(Suppl 2):P372.

Submit your next manuscript to BioMed Central and take full advantage of:

- Convenient online submission

- Thorough peer review

- No space constraints or color figure charges

- Immediate publication on acceptance

- Inclusion in PubMed, CAS, Scopus and Google Scholar

- Research which is freely available for redistribution 